\title{
ARCHIWUM PARTII POLITYCZNYCH ISP PAN W NAUKOWEJ I SPOŁECZNEJ PRZESTRZENI KOMUNIKACYJNEJ*
}

Archiwum Partii Politycznych (APP ISP PAN) istnieje w strukturze Instytutu Studiów Politycznych PAN od 1993 roku. Jego początkiem była baza danych o podmiotach, działających na polskiej scenie politycznej, przygotowana na potrzeby Biura Studiów i Analiz Senatu I kadencji. Przed pierwszymi wolnymi wyborami parlamentarnymi na jesieni 1991 roku uzyskałam już możliwie pełne informacje na temat aktywnych w tym czasie partii i ugrupowań politycznych: ich historii, struktury oraz programów. Gdy w 1993 roku rozpoczęłam pracę w Pracowni Najnowszej Historii Politycznej ISP PAN, jej kierownik, Andrzej Paczkowski, postawił przede mną zadanie utworzenia Archiwum Partii Politycznych. Jego zalążkiem stały się zebrane dla Senatu dokumenty polskich ugrupowań politycznych z lat 1991-1993 (przekazane za zgodą ówczesnego dyrektora BSiA Senatu Jacka Michałowskiego) oraz moje własne zbiory materiałów politycznych z okresu przełomu ustrojowego w Polsce. Obecnie Archiwum Partii Politycznych funkcjonuje przy Zakładzie Najnowszej Historii Politycznej ISP PAN, kierowanym przez Andrzeja Friszkego.

Do statutowych zadań Archiwum należy dokumentacja działalności i myśli programowej polskich partii i ugrupowań politycznych poprzez następujące działania:

- pozyskiwanie i gromadzenie dokumentów partyjnych,

\footnotetext{
* archiwumpartiipolitycznych.pl/
} 
— archiwizację i digitalizację zbiorów, opracowanie katalogów i inwentarzy,

— udostępnianie zasobów,

- prace analityczne oraz edycję źródeł i innego rodzaju publikacje.

Pomimo trudnych warunków lokalowych i finansowych oraz niewielkiego grona pracowników Archiwum działa nieprzerwanie od 25 lat i gromadzi zbiory stanowiące źródło wiedzy na temat ponad stu polskich partii i ugrupowań politycznych ${ }^{1}$.

\section{PRZESŁANKI POWSTANIA I DZIAŁALNOŚCI APP ISP PAN}

Przypomnę, że w czasach PRL debata publiczna była stłumiona, a jeżeli już się toczyła, to głównie w domach prywatnych, a od drugiej połowy lat siedemdziesiątych XX wieku - w opozycyjnych pismach tzw. drugiego obiegu. Okres legalnego działania Solidarności (od września 1980 roku do grudnia $1981 \mathrm{roku}$ ) to zarazem czas intensywnego rozwoju społecznej przestrzeni komunikacyjnej. W sferze publicznej toczyły się niekończące się dyskusje polityczne o fundamentalnym znaczeniu. Ich zwieńczeniem był I Krajowy Zjazd Delegatów NSZZ „Solidarność” (wrzesień-październik 1981 r.) i przyjęta wówczas platforma programowa. Po wprowadzeniu przez władze PRL stanu wojennego dyskusje polityczne powróciły do sfery prywatnej, ale odbywały się również w murach kościołów, uczelni wyższych i w niektórych stowarzyszeniach (np. w Polskim Towarzystwie Socjologicznym, w Klubach Inteligencji Katolickiej) ${ }^{2}$.

Kiedy w Polsce nadszedł przełomowy rok 1989, ten wymiar aktywności ludzkiej - podobnie jak w pierwszym okresie legalnej działalności Solidarności - natychmiast zaczął się odbudowywać w przestrzeni społecznej. Debaty polityczne toczyły się w trakcie kampanii wyborczych do Sejmu X kadencji i Senatu I kadencji, następnie - na forum wybranego w czerwcu 1989 roku parlamentu, a także w uwolnionych od wieloletniej cenzury mediach. Bardzo żywe były dyskusje o sprawach publicznych w obrębie stowarzyszeń społecznych, w tym szczególnie ważną rolę należy przypisać debacie ruchu komitetów obywatelskich (była to druga - obok Obywatelskiego Klubu Parlamentarnego - najważniejsza płaszczyzna, na

${ }^{1}$ Zob. Inka Słodkowska, Dwudziestolecie Archiwum Partii Politycznych Instytutu Studiów Politycznych PAN, w: Wybory 2011. Partie i ich programy, Instytut Studiów Politycznych PAN, Warszawa 2013.

2 Zob. Inka Słodkowska, Społeczeństwo obywatelskie na tle historycznego przełomu. Polska 1980 -1989, Instytut Studiów Politycznych PAN, Warszawa 2006. 
której tworzone były projekty ustrojowe i polityczne). Artykułowano wówczas - bardzo nieraz od siebie odmienne — opinie i oceny bieżącej sytuacji politycznej i społecznej, a w ślad za tym pojawiały się pewne postulaty działania. W celu ich realizacji powstawały środowiska, które przyjmowały konkretną postać organizacyjną. Część z nich przekształcała się w partie polityczne. W procesie tym uczestniczyły także istniejące już środowiska polityczne, zarówno "protopartie” opozycyjne ${ }^{3}$, jak i oficjalne ugrupowania partyjne $z$ czasów $\mathrm{PRL}^{4}$. Do nich dołączali nowi aspiranci do odgrywania jakiejś roli politycznej.

Należy przy tym zauważyć mechanizm leżący u podłoża zjawiska masowego powstawania partii politycznych na początku lat dziewięćdziesiątych. Wiele ciał, które rejestrowały się wówczas jako partie polityczne, de facto było stowarzyszeniami, formułującymi partykularne cele swoich członków jako założenia ideowe i zadania do realizacji. W tym czasie bowiem łatwiej było założyć partię polityczną niż organizację społeczną. Ustawa o stowarzyszeniach, uchwalona przez Sejm PRL IX kadencji na początku 1989 r., stawiała wysokie wymogi i nakładała liczne i skomplikowane obowiązki przy rejestracji ${ }^{5}$. Natomiast do zarejestrowania partii zgodnie z Ustawa o partiach politycznych z 28 lipca 1990 roku wystarczały podpisy piętnastu osób pod zawiadomieniem o jej powstaniu oraz przedstawienie pewnego - nawet bardzo hasłowego - statutu. Można zatem zasadnie przypuszczać, że część osób mających potrzebę publicznego wyartykułowania czy realizacji jakiegoś postulatu lub idei zakładała partię zamiast stowarzyszenia. Znamienny w tym kontekście jest fakt, że były to najczęściej ciała efemeryczne, co można wyjaśniać tym, że ich forma organizacyjna nie była adekwatna do stawianych celów, w związku czym nie wypełniały swych zadań - po niedługim czasie więc ich działalność zamierała lub ulegały samorozwiązaniu.

Całość tych zjawisk, omówionych tu w dużym skrócie, zakreślała ramy przestrzeni, którą można opisać jako nową, demokratyczną scenę politycz-

3 Takie jak: Polska Partia Socjalistyczna, Stronnictwo Pracy, Dziekania, Ład i Wolność, Centrum Demokratyczne, Konfederacja Polski Niepodległej, Solidarność Walcząca (zob. Małgorzata Dehnel-Szyc, Jadwiga Stachura, Gry polityczne: orientacje na przyszłość, Volumen, Warszawa 1991).

${ }^{4}$ Były to: Polska Zjednoczona Partia Robotnicza, Zjednoczone Stronnictwo Ludowe, Stronnictwo Demokratyczne, Stowarzyszenie PAX, Unia Chrześcijańsko-Społeczna, Polski Związek Katolicko-Społeczny.

${ }^{5}$ Ustawa ta była szeroko dyskutowana przez środowiska niezależne, a negocjowana z władzami między innymi przez przedstawicieli prawnych Kościoła katolickiego — Jana Olszewskiego i Wiesława Chrzanowskiego. 
ną tworzącą się w Polsce okresu transformacji ustrojowej ${ }^{6}$. „Demokracja nie jest systemem idealnym, a jej rzeczywiste funkcjonowanie wykazuje wiele nieusuwalnych $\mathrm{w}$ istocie wad, także $\mathrm{w}$ aspekcie politycznym i etycznym, takich jak siła interesów partykularnych, przetrwanie struktur oligarchicznych czy istnienie elementów "niewidzialnej władzy»" ${ }^{7}$. Mimo wskazanych niedoskonałości ten typ ustroju politycznego w czasach nowożytnych oceniany jest najwyżej, zarówno jako idea, jak i na poziomie pragmatycznym. Partie polityczne - jako narzędzia obywatelskiej partycypacji stanowią immanentny element demokratycznych ustrojów państwowych. Są to dobrowolne stowarzyszenia obywateli powoływane w celu artykulacji i agregacji interesów/wartości społecznych oraz wspólnego działania ich członków. Klasyczne definicje jako konstytutywny element partii politycznej wskazują dążenia do uzyskania kontroli nad kierunkami polityki państwowej poprzez wprowadzenie swoich przedstawicieli do organów władzy. Jest to droga do realizacji interesów/wartości danej struktury politycznej (trzeba zaznaczyć, że stać za tym mogą motywy rozmaitej proweniencji, na przykład religijne czy „poszukiwanie posad”). Podstawowym celem każdej partii jest zatem zwycięstwo w konkurencji z innymi ciałami politycznymi podczas elekcji: parlamentarnych, prezydenckich, samorządowych. Partie przedstawiają wyborcom swoich kandydatów i manifesty wyborcze zawierające programy działania: polityczny, gospodarczy, społeczny i in. Poparcie uzyskane w wyborach daje mandat do uzyskania decydującego wpływu na życie państwowe i społeczne.

Losy demokracji - czyli to, kto będzie sprawował władzę i podejmował rozstrzygnięcia co do kluczowych kwestii państwowych i społecznych — zależą zatem od obywateli, którzy podejmują określone decyzje wyborcze. $\mathrm{Z}$ tych względów duże znaczenie dla demokracji trzeba przypisać czynnikom takim jak wiedza i kultura polityczna elektoratu. Archiwum Partii Politycznych powstało w celu badania i dokumentacji procesu tworzenia się, a następnie - rozwoju sceny politycznej w demokratycznej Polsce. Jednakże założeniem fundamentalnym, które zostało sformułowane na początku istnienia tej placówki, było i jest prowadzenie edukacji obywatelskiej, czyli udostępnianie oraz upowszechnianie szerokiej i rzetelnej wiedzy na temat polskich partii politycznych.

${ }^{6}$ Zob. Ewa Nalewajko, Protopartie i protosystem?. Szkic do obrazu polskiej wielopartyjności, Instytut Studiów Politycznych PAN, Warszawa 1997.

7 Marek Ziółkowski, Barbara Pawłowska, Rafał Drozdowski, Jednostka wobec władzy, Wydawnictwo Nakom, Poznań 1994, s. 53. 


\section{ARCHIWUM PARTII POLITYCZNYCH: ZASOBY, METODOLOGIA I FORMY DZIAŁANIA}

Przed przystąpieniem do omówienia zasad działania APP ISP PAN należy zaznaczyć, że jest ono placówką, która w oczywisty sposób nie spełnia wszystkich wymogów, jakie zostały zapisane w słownikowej definicji tego pojęcia:

„Archiwum, 1) zdefiniowany i uporządkowany zbiór dokumentów; 2) instytucja (lub jej część) zajmująca się ich gromadzeniem, klasyfikowaniem i przechowywaniem; 3) Budynek, w którym się one znajdują. [...] Tworzenie archiwów ma zwykle charakter organizowany: są one efektem produktywności instytucji (społeczności, jednostki), systematycznie decydujących, że pewne jej wytwory nie są już potrzebne w bieżących praktykach i mogą zostać usunięte z zasobów podręcznych, choć jednocześnie powinny zostać zapamiętane [...], trwale chronione w celu zachowania dla pamięci i ewentualnego przyszłego użycia" 8 .

Polskie partie polityczne nie stworzyły wspólnego archiwum. Niestety, nie istnieje obowiązek przekazywania przez partie „egzemplarzy obowiązkowych" swoich dokumentów do jakiejkolwiek placówki archiwalnej ${ }^{9}$. APP ISP PAN — jako instytucja naukowa — nie jest zatem miejscem przyjmowania dokumentów przekazywanych przez partie polityczne w celu ich zbierania, porządkowania i klasyfikowania, lecz stanowi projekt badawczy. Można je przyrównać do biblioteki, do której zasobów stale są zdobywane i włączane nowe, cenne woluminy. Materiały partyjne znalazły się w APP ISP PAN — co należy podkreślić - w wyniku aktywnych poszu-

\footnotetext{
${ }^{8}$ Iwona Kurz, Archiwum, w: Magdalena Saryusz-Wolska, Robert Traba (red.), Joanna Kalicka (współpr.), Modi memorandi. Leksykon kultury pamięci, Scholar, Warszawa 2014, s. 45.

9 W zasobach Archiwum Akt Nowych w Warszawie znajdują dokumenty 31. polskich partii politycznych, otrzymane od ich likwidatora, reprezentującego Krajowy Rejestr Sądowy. Jak ocenia dyr. Tadeusz Krawczak, „poza dokumentami dotyczącymi czynności likwidacyjnych, materiałów istotnych od strony merytorycznej nie ma [tam] wcale". Większą wagę przedstawia natomiast szesnaście zespołów dokumentów partyjnych bezpośrednio przekazanych do AAN przez polityków lub ich spadkobierców. Są to między innymi archiwa takich partii, jak Porozumienie Centrum, Chrześcijańska Demokracja III RP, Polskie Forum Chrześcijańsko-Demokratyczne, Stronnictwo Pracy, PSL Mikołajczykowskie, jak i archiwa/spuścizny takich polityków, jak Tadeusz Mazowiecki, Bronisław Geremek, Władysław Siła-Nowicki, Zbigniew Romaszewski, Wiesław Chrzanowski, Janusz Zabłocki. Zob.: T. Krawczak, „Odważmy się być wolnymi”. Materiaty archiwalne po środowiskach niepodległościowych w zasobie AAN, w: Rola opozycji niepodległościowej w ksztattowaniu polskiej sceny politycznej w źródłach okresu przełomu i wspótczesnej narracji. Materiały VI ogólnopolskiego seminarium: Archiwa przełomu 1989-1991. Wspólny Projekt Kancelarii Prezydenta RP $i$ Kancelarii Senatu, Kancelaria Prezydenta Rzeczypospolitej Polskiej, Warszawa 2019, s. 139-144.
} 
kiwań badawczych pracowników tej placówki ${ }^{10}$. Od początku działalności Archiwum został przyjęty paradygmat badawczy, zgodnie z którym kwerendą objęte są te partie, które posiadały (posiadają) reprezentacje parlamentarne, brały udział w wyborach parlamentarnych, samorządowych i eurowyborach oraz/lub wysuwały swego kandydata/kandydatkę w wyborach prezydenckich ${ }^{11}$. Kwerendy są podejmowane na kilku poziomach: (1) całości struktury politycznej, (2) w wymiarze jej segmentów, na przykład koalicje partyjne, (3) w wymiarze poszczególnych partii i ugrupowań politycznych, (4) w sferze parlamentarnej i rządowej, (5) na poziomie programowym. Dokumenty oraz inne wytwory partii politycznych pozyskujemy w strukturach partyjnych, w siedzibach klubów i kół parlamentarnych, a także od osób prywatnych. Prowadzimy także kwerendy na stronach internetowych, prasowe, biblioteczne, archiwalne oraz $\mathrm{w}$ rejestrach sądowych.

Innymi słowy - materiały na temat poszczególnych partii uzyskujemy $z$ różnych źródeł.

Po pierwsze - bezpośrednio $\mathrm{w}$ danej partii, w jej siedzibach oraz poprzez partyjne publikacje, strony internetowe, portale $\mathrm{w}$ mediach społecznościowych. Odbywa się to za pośrednictwem kontaktów osobistych z działaczami i działaczkami partyjnymi (w celu pozyskiwania i weryfikacji informacji, przeprowadzania wywiadów, zbierania relacji). Śledzimy również oficjalne wypowiedzi przedstawicieli danego ugrupowania w mediach. W ten sposób pozyskiwane są także akcesoria partyjne oraz plakaty, ulotki, gadżety wyborcze, które tworzą osobne kolekcje archiwalne.

Po drugie - $-\mathrm{w}$ instytucjach publicznych (przede wszystkim: sąd rejestrowy i Państwowa Komisja Wyborcza). Są to ważne źródła oficjalnych informacji na temat partii politycznych (zwłaszcza dotyczących ich historii oraz działania ciał statutowych) oraz niejednokrotnie miejsca pozyskiwania cennych dokumentów.

Po trzecie - poprzez media (radio, telewizja, internet i media społecznościowe), które dostarczają jednak informacji przetworzonej, o różnym stopniu wiarygodności, wymagającej weryfikacji.

Po czwarte - publikacje drukowane i internetowe, zarówno naukowa literatura przedmiotu, jak i inne wydawnictwa dotyczące sceny politycznej.

\footnotetext{
10 Stwierdzenie to dotyczy zdecydowanej większości zbiorów APP ISP PAN, choć w jego zasobach znajdują się również zespoły dokumentów przekazanych przez osoby fizyczne lub instytucje.

${ }^{11}$ Zob. Programy partii i ugrupowań parlamentarnych 1989-1991, zebrała i opracowała Inka Słodkowska, Instytut Studiów Politycznych PAN, Warszawa 1995, s. XI.
} 
W obrębie Archiwum te pozyskane z wielorakich źródeł wytwory tworzą „serie” - zbiory, na które składają się elementy mające „wspólny mianownik", czyli - dokumenty oraz wytwory przypisane do poszczególnych partii oraz inne materiały $z$ tymi ugrupowaniami powiązane. $\mathrm{Na}$ podstawowy zasób archiwalny składają się następujące grupy materiałów:

- dokumenty programowe przyjęte przez statutowe władze partii (np. radę naczelną, zarząd główny, zjazd, kongres);

- uchwały, oświadczenia, apele i inne tego typu dokumenty, wyrażające stanowisko władz partii wobec kluczowych wydarzeń czy zagadnień politycznych i społecznych, oficjalne dokumenty artykułujące poglądy i opinie członków partii jako całości oraz prasa i wydawnictwa partyjne;

- oświadczenia, interpelacje, inicjatywy ustawodawcze i inne dokumenty parlamentarne (np. biuletyny klubów parlamentarnych);

- bieżące wypowiedzi liderów partii, jej rzeczników prasowych i innych reprezentantów, opublikowane lub w inny sposób udostępnione opinii publicznej za pośrednictwem prasy i pozostałych mediów;

- dokumenty wyborcze (wybory parlamentarne i prezydenckie): materiały własne partii, listy jej kandydatów oraz dokumenty złożone przy rejestracji komitetu wyborczego i kandydatów w Państwowej Komisji Wyborczej;

— inne dokumenty, na przykład materiały pozyskane w wyniku kwerendy archiwalnej, prasowej, bibliotecznej i sądowej (np. w sądzie rejestracyjnym), relacje „świadków historii”, wywiady z politykami, materiały audiowizualne (nagrania, fotografie itp.);

- literatura przedmiotu badań (monografie i artykuły naukowe, materiały pokonferencyjne) oraz wydawnictwa innego rodzaju (np. analizy produkowane przez think tanki, wspomnienia polityków lub książkowe wywiady $z$ nimi).

W skład zgromadzonego zasobu wchodzą także: księgozbiór tematyczny i archiwum prasowe oraz — chronologicznie najnowsze - archiwum partyjnych stron internetowych i mediów społecznościowych (głównie: Facebook, Twitter). Obecnie w Archiwum zgromadzonych jest 30 m.b. materiałów drukowanych, a plików elektronicznych - 49,4 GB.

Archiwum posiada również wiele dokumentów i wydawnictw politycznych $\mathrm{z}$ lat osiemdziesiątych XX wieku oraz z przełomu lat osiemdziesiątych i dziewięćdziesiątych. Są to głównie materiały publikowane drukiem (w tzw. drugim obiegu) przez opozycję polityczną (różnych opcji), ale obok nich w zbiorach znajdują się dokumenty organizacji oficjalnie działających w czasach PRL (np. OPZZ, PAX czy Stowarzyszenia „Grunwald”). W wyniku realizacji projektu badawczego „Dokumenty przełomu. Polska 
transformacja ustrojowa w latach 1989-1991 w dokumentach Obywatelskiego Klubu Parlamentarnego, Komitetu Obywatelskiego przy Przewodniczącym NSZZ «Solidarność» oraz Komitetów Obywatelskich «Solidarność»" 12 została zgromadzona i opracowana ważna dokumentacja okresu przełomu ustrojowego w Polsce (dokumenty podmiotów badanych w ramach projektu, relacje i wywiady ze „świadkami historii”, publikacje, prasa, fotografie, plakaty, ulotki wyborcze itd.). Całość tej dokumentacji jest dostępna w siedzibie Archiwum Partii Politycznych w Instytucie Studiów Politycznych PAN ${ }^{13}$.

Zasoby Archiwum są na bieżąco opracowywane i archiwizowane. Obecnie trwa proces ich digitalizacji oraz intensywne prace nad rozwojem działającej od 2018 roku strony internetowej. Zespół Archiwum dokłada wszelkich starań, aby te zbiory stanowiły repozytorium archiwalne jak najobszerniejsze i jak najwierniej odzwierciedlające działalność oraz myśl programową działających w Polsce partii i ugrupowań politycznych.

\section{APP ISP PAN W PRZESTRZENI KOMUNIKACJI NAUKOWEJ}

W pracy badawczej Archiwum wykorzystujemy szereg paradygmatów teoretycznych oraz zróżnicowane metodologie badawcze: analizy politologiczne i socjologiczne, kwerendy archiwalne, biblioteczne, prasowe i in. (pozyskiwanie dokumentów historycznych oraz innych materiałów źródłowych), metody jakościowe (np. analizy narracyjne, zbieranie relacji oraz wywiady ze świadkami historii). Odwołujemy się także do ilościowych metod badań nad społeczeństwem jako elektoratem.

Zespół Archiwum wykonuje analizy na temat polskiej sceny politycznej dla placówek naukowych i innych instytucji w Polsce i zagranicą, jak urzędy państwowe, oficyny wydawnicze oraz fundacje, think tanki i inne organizacje pozarządowe ${ }^{14}$. Sposób badania programów wyborczych wy-

12 Grant realizowany w latach 2014-2018 pod kierunkiem Inki Słodkowskiej - NPRH 0062/NPRH3/\#11/82/2014.

${ }^{13}$ www.dokumenty-przelomu.pl

${ }^{14}$ Były to m. in.: Centre of European Security Studies, Transparency International Poland, Bank Światowy, Wydawnictwo Sejmowe, Kancelaria Prezydenta RP, Biuro Studiów i Analiz Senatu, Archiwum Senatu, Kluby Parlamentarne Akcji Wyborczej Solidarność i Unii Wolności, Ogólnopolska Federacja Organizacji Pozarządowych, Wydział Politologiczny Uniwersytetu im. Masaryka w Brnie, Department of Politics and International Relations University of Kent, Fundacja im. Stefana Batorego. Dane przygotowane przez APP wykorzystano na przykład w międzynarodowym projecie badawczym, zob. Jaap Woldendorp, Hans Keman, Ian Budge, Party Government in 48 Democracies (1945-1998): Composition - Duration - Personnel, Kluwer Academic Publischers, Dordrecht-Boston-London 2000. 
pracowany w APP ISP PAN jest wykorzystywany w opracowaniach innych autorów ${ }^{15}$.

Dokumenty partyjne należą do zasobu kultury narodowej i stanowią unikatowe źródła informacji dla przedstawicieli wielu dziedzin nauki. Są zarazem przejawem aktywności ludzkiej, przynależą do określonej epoki historycznej i mogą być analizowane jako nośnik wiedzy historycznej o społeczeństwie i jego kulturze. Umożliwiają naukowe badania nad stylem funkcjonowania elit politycznych, ewolucją programów partii, mogą służyć do analiz przyczyn i charakteru zaangażowania partyjnego, jak i do badań nad powstawaniem i działalnością ruchów politycznych. W tym celu zespół Archiwum prezentuje swe zbiory na stronie internetowej oraz przygotowuje publikacje książkowe, przede wszystkim dokumentujące wybory krajowe (parlamentarne i prezydenckie) oraz wybory do parlamentu europejskiego. Od 2013 roku publikacje te ukazują się jako seria wydawnicza Wybory w Wolnej Polsce (redaktor naukowy serii: Inka Słodkowska). Zawierają one manifesty oraz inne dokumenty komitetów wyborczych, przyjęte przez władze danej partii czy inne gremium wystawiające swoich kandydatów do elekcji. Książki te mają charakter krytycznej edycji źródeł historycznych, opracowanych i opatrzonych przypisami, bibliografią oraz indeksami. Zawierają również artykuły analityczne, wprowadzające w temat i problematykę publikacji. Od początku istnienia Archiwum do chwili obecnej ukazało się ponad dwadzieścia pozycji (wydanych nakładem Instytutu Studiów Politycznych, jedna — nakładem Wydawnictwa Sejmowego).

APP ISP PAN współpracuje $z$ wieloma placówkami badawczymi oraz instytucjami archiwalnymi w całym kraju (Archiwum Państwowej Komisji Wyborczej, Archiwum Senatu, Biblioteka Sejmowa i Archiwum Sejmu, Archiwum Prezydenta RP, Biblioteka Narodowa, Archiwum Akt Nowych i Instytut Pamięci Narodowej oraz ich terenowe oddziały, Archiwum Komisji Krajowej NSZZ „Solidarność”, Stowarzyszenie „Archiwum Solidarności”), z uczelniami wyższymi oraz bibliotekami w całym kraju. APP ISP PAN należy do grona uczestników i realizatorów projektu „Archiwa Przełomu 1989-1991" (wspólny projekt Kancelarii Prezydenta RP i Kancelarii Senatu pod honorowym patronatem Prezydenta RP; Inka Słodkowska kierująca APP ISP PAN — jest członkinią i sekretarzem Rady Programowej tego projektu).

${ }^{15} \mathrm{~Np}$. w publikacji OFOP z 2008 roku: Piotr Głowacki, Ryszard Skrzypiec, Raport z realizacji przez partie polityczne obietnic wyborczych dotyczacych społeczeństwa obywatelskiego $w V$ kadencji Parlamentu 2005-2007. 
Dzięki zebranej i opracowanej przez archiwum dokumentacji akcji wyborczych polskich partii politycznych umożliwione zostały badania w wielu obszarach nauki $\mathrm{Na}$ ich podstawie powstało wiele prac magisterskich, doktorskich i habilitacyjnych (głównie $z$ dziedziny politologii, historii, socjologii polityki i prawa), a także artykuły naukowe i prasowe, ekspertyzy oraz inne publikacje autorów polskich i z zagranicy.

\section{APP ISP PAN W PRZESTRZENI KOMUNIKACJI SPOŁECZNEJ}

Komunikacja społeczna to ważny aspekt systemów demokratycznych. Archiwum zarówno pozyskując, jak i udostępniając dokumenty partyjne działa jako użytkownik przestrzeni komunikacji społecznej, stając się zarazem uczestnikiem debaty publicznej. Udział w życiu politycznym, także w wyborach, to istotna forma takiego uczestnictwa.

Pozycja danej partii politycznej w znacznej mierze zależy od tego, jakie miejsce potrafi ona zająć w przestrzeni komunikacji społecznej. Decyduje o tym wiele czynników, obecnie w znacznej mierze umiejętności marketingowe liderów danego ugrupowania, jednak nadal istotne znaczenie ma partyjna oferta programowa. Jej treść (meritum przekazu) oraz sposób prezentacji (stylistyka i retoryka) pozwalają społeczeństwu ocenić, jakie są możliwości danej partii w zakresie kreowania skutecznej polityki i umiejętności rządzenia państwem. Programy polityków odwołują się do dominujących w społeczeństwie systemów wartości i interesów, które stanowią oś krystalizacji zarówno grup i ruchów społecznych, jak i partii politycznych. Poglądy formułowane przez odniesienie do tych wartości i interesów składają się na dyskurs społeczny ${ }^{16}$. Zasoby Archiwum, wydawane przez tę placówkę publikacje oraz strona internetowa umożliwiają prześledzenie tego dyskursu zarówno w wymiarze synchronicznym, jak i diachronicznym. W ten sposób tworzy się pole dla przewidywania działań poszczególnych podmiotów politycznych w sferze społecznej, państwowej czy gospodarczej, ich oceny przez porównania na przykład między deklaracjami wyborczymi a faktycznie realizowaną polityką i priorytetami kolejnych ekip rządzących.

Archiwum poprzez udostępnianie dokumentów partyjnych zwiększa transparentność sceny politycznej w Polsce, pełniąc poniekąd taką rolę jak organizacje pozarządowe określane jako watch dog. Ma wpływ na funkcjonowanie systemu demokracji parlamentarnej w obszarach: podejmowania

16 Szerzej na ten temat zob. Marek Ziółkowski, Przemiany interesów i wartości społeczeństwa polskiego: Teorie, tendencje, interpretacje, Wydawnictwo Fundacji Humaniora, Poznań 2000. 
decyzji wyborczych, kontroli działalności partii politycznych przez wyborców oraz - ogólnie - w zakresie edukacji i rozwoju kultury politycznej społeczeństwa.

W tym kontekście trzeba zwrócić uwagę na szczególną konstrukcję APP ISP PAN. Jego zasoby stanowią bowiem zbiór pochodzący z rozmaitych źródeł i wymiarów sceny politycznej, a także z różnych okresów czasowych. Nie zawsze tworzą układ chronologiczny i wyczerpujący. Pozwala to widzieć nasze archiwum nie jako tradycyjną instytucję, opartą na hierarchicznym porządku, chronologii i linearności, która narzuca sposób odczytywania historii ${ }^{17}$, lecz jako narzędzie jej interpretacji $\mathrm{w}$ duchu koncepcji Benjamina Waltera, który jaką jedną z metod opisu przeszłości proponował „technikę montażu” 18 .

\section{PLANY NA PRZYSZŁOŚĆ}

Zadaniem, jakie staje przed zespołem APP ISP PAN w najbliższej przyszłości, jest przekształcenie Archiwum we w pełni nowoczesną placówkę. Podstawowym celem jest zakończenie prac nad bardzo obszernym już zbiorem materiałów partyjnych: ich pełne opracowanie w postaci inwentarzy i katalogów, całościowa digitalizacja oraz udostępnienie na stronie internetowej Archiwum. Do dostępnych czytelnikom zbiorów archiwalnych zostaną włączone jeszcze nieopracowane dokumenty i materiały partyjne. Rezultatem końcowym - spodziewanym w niedalekiej przyszłości - będzie stworzenie słownika polskich partii politycznych, dostępnego również na stronie internetowej Archiwum. Zespół Archiwum planuje również podjęcie prac analitycznych w ramach wybranych „ścieżek tematycznych", kolejne publikacje (edycje źródeł, monografie, artykuły), a także uzupełniające kwerendy badawcze oraz kontynuowanie zbierania relacji i przeprowadzania wywiadów ze „świadkami historii”.

Realizacja wszystkich tych zamierzeń znacząco rozszerzy zasób wiedzy na temat demokratycznej sceny politycznej w Polsce — historii jej powstawania oraz rozwoju - i umożliwi monitorowanie i dokumentowanie jej funkcjonowania na bieżąco. Dla naukowców, studentów i innym użytkowników Archiwum stworzone zostaną uproszczone procedury korzystania z zasobów APP ISP PAN, a udostępnienie zbiorów on-line umożliwi dotarcie do większego grona odbiorców niż dotychczas. Poszerzy się w ten sposób sieć komunikacji naukowej i społecznej, w obrębie której Archi-

17 Zob. Iwona Kurz, Archiwum, cyt. wyd., s. 49.

18 Walter Benjamin, Pasaże, tłum. Ireneusz Kania, Wydawnictwo Literackie, Kraków 2005. 
wum działa - jako źródło wiedzy obywatelskiej oraz narzędzie badawcze pomocne w analizach systemu politycznego w Polsce.

INKA SŁODKOWSKA

Instytut Studiów Politycznych PAN

islod@isppan.waw.pl

\author{
THE ARCHIVE OF POLITICAL PARTIES \\ AT THE INSTITUTE OF POLITICAL SCIENCES \\ OF THE POLISH ACADEMY OF SCIENCES \\ Inka Słodkowska \\ (Institute of Political Studies, Polish Academy of Sciences)
}

\begin{abstract}
This text is devoted to the Political Parties Archive [Archiwum Partii Politycznych; http://archiwumpartiipolitycznych.pl] in the Institute of Political Studies of the Polish Academy of Sciences. The archive has been in operation since 1993 and is presently undergoing reorganization, which chiefly consists in digitalization. The author presents the idea behind the archive, its history, the classification of its resources, and above all, the information that can be found in it. The collected materials (printed, visual, online) provide information not only about the political parties currently operating in Poland (program documents, election campaigns, participation in social and political life) but also information on the period of systemic transformation and the formation of the democratic system from its beginnings, when opposition political circles in the Polish People's Republic were working on plans for the future. The author emphasizes that the main characteristic of the archive is the activeness of its operators in obtaining materials (through queries to parties and state institutions, interviews with politicians, and monitoring election campaigns, including the archivization of audio-visual materials). The aim is to understand the mechanisms of political life. The Archive is supposed to have an educational function and by making its information accessible it should increase the transparency of political life.
\end{abstract}

Key words / słowa kluczowe

social archive / archiwum społeczne, systemic transformation in Poland / transformacja ustrojowa w Polsce, political life in Poland / życie polityczne w Polsce 